\title{
Sequence completion, identification and definition of the fengycin operon in Bacillus subtilis 168
}

\author{
Valentina Tosato, ${ }^{1}$ Alessandra M. Albertini, ${ }^{2}$ Michela Zotti, ${ }^{1}$ \\ Sabrina Sonda ${ }^{1}$ and Carlo V. Bruschi ${ }^{1}$ \\ Author for correspondence: Carlo V. Bruschi. Tel: +3940 375 7304. Fax: +3940375 7343. \\ e-mail: bruschi@icgeb.trieste.it
}

1 Microbiology Group, International Centre for Genetic Engineering and Biotechnology and ITALTBS Ricerche, Srl, AREA Science Park, Padriciano 99, 1-34012 Trieste, Italy

2 Department of Genetics and Microbiology

'A. Buzzati Traverso', University of Pavia, 27100 Pavia, Italy

\begin{abstract}
A 15 kb DNA fragment from the Bacillus subtilis chromosome between citB and ppsC has been sequenced, and new ORFs encoding putative enzymes involved in lipopolypeptide synthesis, which complete a partial operon previously reported, and a new set of enzymes responsible for lipid metabolism have been identified. From the analysis of DNA sequence homology of the fragment it was deduced that these new peptide synthetase genes are part of an operon for the biosynthesis of the fungicide fengycin.
\end{abstract}

Keywords: antifungal antibiotic, Bacillus subtilis, fengycin, lipopeptide synthetase

\section{INTRODUCTION}

Of the secondary metabolites of biotechnological relevance produced by Bacillus subtilis, lipopolypeptides with antimicrobial activity are among the most important. These small molecules, some of which, such as gramicidin, iturins and surfactins, are well known (Tomino et al., 1967; Maget-Dana \& Peypoux, 1994; Ullrich et al., 1991), are synthesized nonribosomally, through a thioester template mechanism, by synthetases that show a highly conserved structural organization into specific peptide-binding domains (Kleinkauf \& von Döhren, 1990; Turgay et al., 1992; Stachelhaus et al., 1995).

Through the systematic DNA sequencing of the chromosome of $B$. subtilis strain 168 , the initial characterization of part of a large multienzyme complex putatively involved in the biosynthesis of a new lipopolypeptide has been described (Tognoni et al., 1995). This region comprised three genes: pps orf1, pps orf 2 and, partially, $p p s$ orf 3 . A corresponding transcriptional unit has been genetically dissected by transposon mutagenesis in strain F29-3 (Chen et al., 1995) and found to encode the multienzyme complex responsible for the biosynthesis of fengycin, the amino acid composition of

The EMBL accession number for the sequence reported in this paper is Y13917. which was studied by Vanittanakom \& Loeffler (1986). While in the latter strain fengycin production can be demonstrated in a specific bioassay, in strain 168 production has not yet been proven.

In the present paper, we report the completion of the DNA sequencing of the genes specifying the entire polypeptide complex and the analysis of its structural organization. The 3 '-end of a fourth ORF has been found together with a complete ORF encoding a fifth putative enzyme, which is similar to the fen $B$ gene product sequenced by Chen et al. (1995). A transcription termination signal is located immediately downstream of the putative operon. The portion of the chromosomal sequence between the truncated pps orf3 and the last part of the fourth gene that we characterized was obtained from the Pasteur database of the B. subtilis DNA sequence. Based upon the analysis of all the ORFs, we concluded that this five-gene operon encodes a multienzyme complex similar to that responsible for the biosynthesis of fengycin in strain F29-3. Moreover, on the $3^{\prime}$-side of the fifth gene we discovered six ORFs encoding enzymes putatively involved in fatty acid metabolism.

\section{METHODS}

Bacterial strains, plasmids and culture conditions. B. subtilis $168 \operatorname{trp} C 2$ from Institut Pasteur (Paris, France) was used as the source of chromosomal DNA for PCR amplifications of the 
Table 1. Plasmids used in this study

\begin{tabular}{|c|c|}
\hline Plasmid & Description (source or reference) \\
\hline pBSKII/pBKSII & Ap; integrative vector (Short et al., 1988) \\
\hline pUC18 & Ap; integrative vector (Yanisch-Perron et al., 1985) \\
\hline pDIA5304 & Ap Cm; vector used for chromosome walking (Glaser et al., 1993) \\
\hline pCE18 & $\begin{array}{l}15 \cdot 3 \mathrm{~kb} \text { in pDIA5304 obtained by chromosome walking (Glaser et al., } \\
1993 \text { ) }\end{array}$ \\
\hline pCE19 & $8 \cdot 3 \mathrm{~kb} \mathrm{BamHI-SacI}$ chromosomal fragment cloned into pBKSII \\
\hline pCE20 & $7 \cdot 0 \mathrm{~kb}$ BamHI-XhoI fragment from pCE18 cloned into pBSKII \\
\hline pVA1 & $3.6 \mathrm{~kb}$ Sacl-HindIII fragment from pCE19 cloned in pBSKII \\
\hline pVA2 & $2.4 \mathrm{~kb}$ HindIII fragment from pCE19 cloned in pBSKII \\
\hline pVA3 & $1.5 \mathrm{~kb}$ HindIII fragment from pCE19 cloned in pBSKII \\
\hline pVA4 & $0.4 \mathrm{~kb}$ HindIII fragment from pCE19 cloned in pBSKII \\
\hline pVAS & $0.3 \mathrm{~kb}$ HindIII fragment from pCE19 cloned in pBSKII \\
\hline pVL1 & $1.7 \mathrm{~kb}$ Dral-Sacl fragment from pVA1 cloned in pBSKII \\
\hline $\mathrm{pVL2}$ & $1 \cdot 2 \mathrm{~kb}$ DraI fragment from pVA1 cloned in pBSKII \\
\hline pVL3 & $0.8 \mathrm{~kb}$ DraI-HindIII fragment from pVA1 cloned in pBSKII \\
\hline pVE1 & $0.3 \mathrm{~kb}$ DraI-HindIII fragment from pVA2 cloned in pBSKII \\
\hline pVE2 2 & $1.4 \mathrm{~kb}$ Dral fragment from $\mathrm{pVA} 2$ cloned in pBSKII \\
\hline pVE3 & $0.5 \mathrm{~kb}$ Dral-HindIII fragment from pVA2 cloned in pBSKII \\
\hline pVN1 & $2.6 \mathrm{~kb}$ Pst I fragment from pCE 20 cloned in $\mathrm{pBSKII}$ \\
\hline pVN2 & $1.1 \mathrm{~kb}$ PstI fragment from pCE20 cloned in pBSKII \\
\hline $\mathrm{pVN} 3$ & $1.0 \mathrm{~kb}$ Pst I fragment from pCE20 cloned in pBSKII \\
\hline pVN4 & $1.8 \mathrm{~kb} \mathrm{BamHI-Pst} \mathrm{I}$ fragment from pCE20 cloned in pBSKII \\
\hline pVT1 & $\begin{array}{l}0.6 \mathrm{~kb} \text { BamHI fragment obtained by PCR amplification on chromosomal } \\
\text { DNA and cloned in pBSKII }\end{array}$ \\
\hline pVI1 & $\begin{array}{l}0.3 \mathrm{~kb} \text { fragment obtained by PCR amplification on chromosomal DNA, } \\
\text { blunt-ended by Klenow enzyme and cloned in pUC18 }\end{array}$ \\
\hline
\end{tabular}

overlapping fragments to be cloned and sequenced. The chromosomal DNA was extracted from overnight cultures as described by Murray \& Thompson (1980).

Escherichia coli DH5 $\alpha$-(supE44 slacU169 $\phi 80$ lacZDM15 hsdR17 recA1 gyrA96 thi-1 relA1 $\mathrm{F}^{-}$) (Gibco-BRL)-competent cells were transformed with the recombinant plasmid pCE19. E. coli and B. subtilis strains were grown aerobically at $37^{\circ} \mathrm{C}$ in Luria-Bertani or Terrific Broth. When necessary, these were supplemented with $100 \mu \mathrm{g}$ ampicillin (Ap) $\mathrm{ml}^{-1}$.

If not indicated otherwise, E. coli XL-1 Blue MRF' $[\Delta(m c r A) 183 \Delta(m c r C B-h s d S M R-m r r) 173$ end $A 1$ supE44 thi-1 recA1 gyrA96 relA1 lac ( $\mathrm{F}^{\prime}$ proAB ${ }^{+}$lacl ${ }^{4}$ lacZ $\Delta \mathrm{M} 15-\mathrm{Tn} 10$ $\left[\right.$ Tet $\left.\left.^{r}\right]\right)$; Stratagene] was used as the recipient strain for cloning experiments.

The plasmids used in this work are listed in Table 1.

Transformation and DNA manipulation. E. coli cells were transformed following the procedure of Hanahan (1985).

Plasmid DNA was isolated from $E$. coli by a modified alkaline lysis procedure (Zhou et al., 1990) and all DNA manipulations were performed as described by Sambrook et al. (1989). Double-stranded DNA templates for sequencing reactions were purified by MicroSpin S-400 HR columns (Pharmacia).

PCR amplification. To complete the contig next to the $p p s D$ gene, a PCR amplification was performed on $B$. subtilis 168 genomic DNA using custom primers with a BamHI recognition site at their end. The forward primer (PF Bam) was a 32-mer with the sequence 5'-CGGGATCCCG-
TCAAAGCGTTACAGGTATCTGC-3' (the underlined bases correspond to the end of $p p s D)$. The reverse primer $(\mathrm{PB} 2$ Bam) was a 31-mer with the sequence $5^{\prime}$-CGGGATCCCGTACCCTAAAGCCAAATCTTCA-3' (the underlined bases correspond to the end of $p p s E)$. PCR was run for 30 cycles in a Prem-ThermoCycler (Lep Scientific) apparatus using the following protocol: denaturation, $3 \mathrm{~min}$ at $94^{\circ} \mathrm{C}$ for the first cycle and $1 \mathrm{~min}$ at $94^{\circ} \mathrm{C}$ thereafter; annealing, $1 \mathrm{~min}$ at $57^{\circ} \mathrm{C}$; elongation, $1 \mathrm{~min}$ at $72^{\circ} \mathrm{C}$. The PCR product was purified by electroelution, then digested with $B a m \mathrm{HI}$ and cloned into pBSKII (Stratagene). The junction between $7 \mathrm{~kb}$ and $8.3 \mathrm{~kb}$ contigs was verified by sequencing a PCR product of about $300 \mathrm{bp}$ obtained with the 22-mer forward primer PD2 $\left(5^{\prime}\right.$-TCGATGCTGTTCATATGGATGA-3' $)$, a custom primer also used for the $7 \mathrm{~kb}$ fragment sequencing, and the 22mer reverse primer PR1 $\left(5^{\prime}\right.$-TTTTGACTTCATTGCTCCACCA $-3^{\prime}$ ), designed at the end of the $8.3 \mathrm{~kb}$ sequence. The 300 bp purified PCR product was cloned by the SureClone Ligation kit into a pUC18 SmaI/BAP vector (Pharmacia).

DNA cloning and sequencing. We received a fragment of approximately $15.3 \mathrm{~kb}$ cloned into a SacI/SmaI-digested pDIA5304 vector (Glaser et al., 1993) from the laboratory of Dr A. Galizzi, University of Pavia, Italy. This recombinant plasmid was recovered by a Campbell-type recombination event and it contains a fragment adjacent to an already known chromosomal marker (Niaudet et al., 1982). The recombinant plasmid was cut with $B a m \mathrm{HI}$ and $X$ hol and the derived $7 \mathrm{~kb}$ fragment was cloned into a pBSKII vector. The fragment was cleaved with PstI into four pieces (about $2.7 \mathrm{~kb}, 1.8 \mathrm{~kb}$ and a doublet of $1.0 \mathrm{~kb}$ ). The remaining $8.3 \mathrm{~kb}$ was obtained from 
the above laboratory as a subclone in a BamHI-SacI-cleaved pBKSII vector. The fragment was subcloned using $H$ indIII and the resulting five fragments $(3.6,2.4,1.5,0.4$ and $0.3 \mathrm{~kb}$, respectively) were inserted in pBSKII. The 3.6 and $2.4 \mathrm{~kb}$ fragments were furthermore cut with DraI and subcloned into blunt-ended EcoRV-digested pBSKII.

All subclones were sequenced on both strands using primer walking by the dideoxy chain-termination method (Sanger $e t$ al., 1977) with plasmid double-stranded DNA as template and a Sequenase version 2.0 sequencing kit (USB). For the sequencing reactions we used M13 universal primers (Stratagene).

Data handling and computer analysis. Autoradiographic films were read manually on an IBI gel reader using the MacVector sequence analysis program (Eastman Kodak). Sequence alignments and verification of the overlaps were performed using the AssemblyLign software package (Eastman Kodak). Preliminary searches for putative ORFs were performed with the IBI/Pustell sequence analysis program (Pustell \& Kafatos, 1984). Final analysis of contiguous DNA sequences and possible translations into proteins were obtained using the GCG software package (Devereux et al., 1984). Amino acid sequences, ORFs and restriction maps were calculated with both the commercial DNA Strider software (Marck, 1988) and the ORFEX program developed in our laboratory (P. Zaccaria \& C. Bruschi, unpublished results). Codon usage and possible frameshift analyses were performed by the GeneMark e-mail server (Borodovsky et al., 1994). The program DNAsis (Pharmacia) was used to design the primers for sequencing. Sequences were compared to those in the GenBank, SBASE (Pongor $e$ t al., 1993) and EMBL databases by the BLAST e-mail server (Altschul et al., 1990). In particular, we used BLASTX, BLASTN and BLASTP for homology searches of nucleotide and amino acid sequences, respectively. Protein homology searches were carried out by FASTA (Pearson \& Lipman, 1988) against the SWISS-PROT, NBRF-PIR and GenPep databases.

\section{RESULTS}

\section{Sequence determination and analysis}

As part of the European Community Biotechnology programme for the systematic sequencing of the $B$. subtilis 168 genome, we were assigned a region located at about $167^{\circ}$ on the circular chromosome which is flanked by the genes $c i t B$ and $p p s C$. Fifteen kilobases (consisting of two contigs of 8.3 and $7 \mathrm{~kb}$ ) were fragmented, subcloned and sequenced as described in
Methods. A preliminary restriction map was initially made on the plasmid clones pCE19 (containing the $8.3 \mathrm{~kb}$ fragment) and pCE20 (containing the $7.0 \mathrm{~kb}$ fragment) to find fragments of suitable size for sequencing. Eleven subclones from the fragmented $8.3 \mathrm{~kb}$ contig and four subclones from the $7 \mathrm{~kb}$ contig were sequenced and these could be located on the basis of the preliminary restriction map. The restriction enzyme $S$ fil does not cleave in this region, but a NotI site was found at $1267 \mathrm{bp}$ (Fig. 1) from the $5^{\prime}$-end of the $7 \mathrm{~kb}$ contig according to the physical map of the chromosome (Itaya \& Tanaka, 1991). The junctions between the restriction fragments were sequenced using pCE19 and pCE20 as templates. A fragment of 131 nucleotides, derived from the Pstl-digested $7 \mathrm{~kb}$ contig, was directly sequenced on pCE20. Because of the difficulties encountered at the level of pCE18 template preparation due to its size (about $20 \mathrm{~kb}$ ), the sequence of the junction between the 8 and $7 \mathrm{~kb}$ contigs was verified by PCR. A product of $413 \mathrm{bp}$ containing the junction was amplified using two primers designed on the two contigs, cloned and sequenced. At the 3 -end of the $8 \mathrm{~kb}$ fragment, following the $S a c$ I site, we found the overlap with the next contig assigned to Karl Entian's group (Frankfurt, Germany). However, when we compared the 5 'end of the $7 \mathrm{~kb}$ sequence with the sequences already deposited at the Pasteur database by the ENIRICERCHE group (G. Grandi, Milan, Italy), we could not find the expected overlap. Therefore, to cover the gap between the $7 \mathrm{~kb}$ fragment and the $3^{\prime}$-end of the fragment allocated to ENIRICERCHE, we designed a primer on each of the two sequences and amplified, cloned and sequenced a DNA fragment of $625 \mathrm{bp}, 260$ of which were new.

We sequenced $15276 \mathrm{bp}$ entirely on both strands. A primer walking strategy allowed us to obtain a good level of accuracy of the sequence with a redundancy factor of 2.0. Since we verified that the systematic use of the dGTP analogue 7-deaza-dGTP did not solve the high number of compressions observed, the ambiguities were solved by using dITP in the reactions. The GC content was $45.3 \mathrm{~mol} \%$, which is slightly higher than the mean value for the $B$. subtilis genome. Since small genes are abundant in B. subtilis (Klier et al., 1992), we decided to perform the sequence analysis using a minimum ORF length of 75 codons.

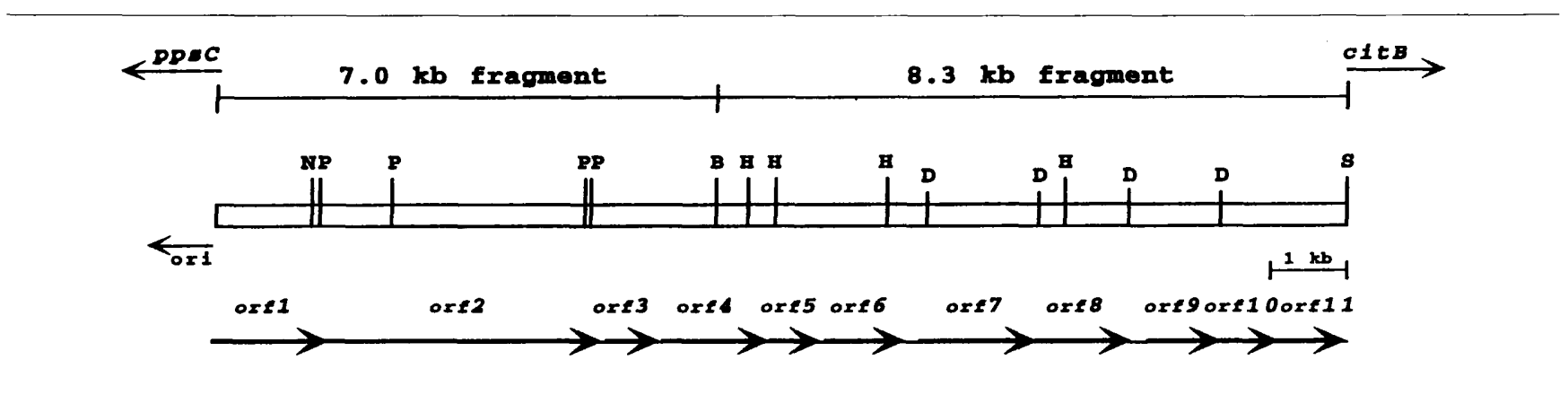

Fig. 1. Schematic representation of the chromosomal location of the $15 \mathrm{~kb}$ region with the relevant restriction sites: $\mathrm{N}$, Notl; P, Pstl; B, BamHI; H, HindIII; D, Dral; S, Sacl. On the bottom, the arrows indicate the orientation of the 11 ORFs found. 
Table 2. General features of the identified ORFs

\begin{tabular}{|ccclc|}
\hline ORF & Gene name & Endpoints (nt) & \multicolumn{1}{c|}{ Translation start* $^{*}$} & Stop codon \\
\hline 1 & $p p s D$ & $1<-1601$ & - & TAA \\
2 & $p p s E$ & $1633-5448$ & AGGTGcagacactATG & TAA \\
3 & yosA & $5562-5951$ & GGAGGcttctcaATG & TAA \\
4 & yot $A$ & $6090-7619$ & GGAGAAgaaacagaATG & TAA \\
5 & yot $B$ & $7893-8195$ & GGAGATgctGTG & TGA \\
6 & yotC & $8289-9428$ & AAGGAGGaaacgatGTG & TAA \\
7 & yotD & $9552-11120$ & GAGATgctgttGTG & TGA \\
8 & yotE & $11133-12464$ & GAGGTGaatcATG & TAA \\
9 & yotF & $12718-13614$ & GAGGAagaccATG & TGA \\
10 & yotG & $13638-14417$ & GGAGGAcgcatacaATG & TAA \\
11 & yot $H$ & $14437->15276$ & AGGGAGGcaatgctgATG & - \\
\hline
\end{tabular}

* The Shine-Dalgarno sequence is in capital letters; the initiation codon is in bold.

Computer-assisted translation of the $15.3 \mathrm{~kb}$ DNA sequence in all six possible reading frames identified at least 40 putative ORFs ( 28 on the 8304 bp fragment and 12 on the 6978 bp fragment) among which, according to the three criteria proposed by Glaser et al. (1993), only 11 represented coding sequences (Fig. 1). The initiation codon appeared to be ATG in seven cases and GTG in three cases (orf5, orf6 and orf7). The sizes and names of the genes, their Shine-Dalgarno consensus sequences and the start and stop codons are shown in Table 2. All putative genes are in the same orientation, opposite to the direction of movement of the replication fork.

\section{Putative ORF products}

Comparison of the amino acid sequences of each putative ORF product with those of proteins available in databases (Table 3) revealed identity of the polypeptide encoded by orf 1 with the carboxy-terminus of the $B$. subtilis peptide synthetase ORF4 (accession number Z34883). Analysis of the 533-aa-long polypeptide revealed significant homology with surfactin synthetase and gramicidin $\mathrm{S}$ synthetase. We therefore assigned the name $p p s D$ to this truncated ORF. The deduced 1272 aa product of orf 2 showed $80 \%$ identity and $89 \%$ similarity over 1223 aa at the amino-terminus with the 1274 aa fengycin synthetase of $B$. subtilis F29-3 (Chen et al., 1995). A CAA codon encoding a glutamine residue present in FenB at position 1224 is missing in ppsE. Therefore, the homology in the remaining carboxy-terminus portion decreases and the genes encoding the two peptides become significantly different (only $35 \%$ identity) in the last 40 nucleotides at the 5 -end and, consequently, in the corresponding amino acids. Comparison of our orf 2 sequence with a sequence deposited in the EMBL database (accession number Z34883) revealed 11 mismatches in 5496 bp of overlap. This results in the substitution of more than 100 aa in the corresponding protein and causes a decrease in hom ology with the fengycin synthetase described by Chen $e t$ al. (1995) (BLASTX scores: 5173 for our protein; 2773 for

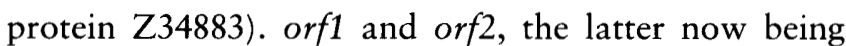
called $p p s E$, seem to be part of an operon, which is followed by a 24 nucleotide palindromic sequence with putative transcription termination function, while no other termination sequences are present between the ORFs.

The functions of orf 3 , orf 4 and orf5 are unknown. The putative products of the remaining ORFs in the $8 \mathrm{~kb}$ contig show significant homology with enzymes of fatty acid metabolism of $B$. subtilis. In particular, the product of orf6 (YotC) shows similarities with acyl-CoA dehydrogenases of bacterial species (up to $52 \%$ identity with this enzyme from Clostridium acetobutylicum) and some mammalian species (up to $56 \%$ identity with the short-chain acyl-CoA dehydrogenase precursor in Homo sapiens and Rattus norvegicus). The deduced orf7 product (YotD) shows similarities with a 4coumarate-CoA ligase of plants $(36,35$ and $33 \%$ identity with Petroselinum crispum, Solanum tuberosum and Oryza sativa, respectively). Furthermore, an interesting homology exists between this enzyme and the long-chain acyl-CoA synthetase of B. subtilis (accession number Z75208) and E. coli (accession number L17309). orf8, which forms an operon with the abovementioned CoA ligase gene, encodes a putative biotin carboxylase $(52 \%$ identity with the corresponding proteins of Methanococcus jannaschii and B. subtilis). This enzyme contains carbamoyl-phosphate synthetase subdomain signatures that are characteristic of several biotin-dependent enzymes, such as acetyl-CoA and propionyl-CoA carboxylases (Waldrop et al., 1994). The last gene in this contig, yot $\mathrm{H}$, which is truncated, shows homology with the amino-terminal part of a peptide similar to the beta chain of a prokaryotic biotindependent propionyl-CoA carboxylase. Therefore, these two enzymes could have related functions and are possibly involved in the first step of fatty acid biosynthesis. The putative protein encoded by orf 9 has $46-47 \%$ identity with the hydroxymethylglutaryl-CoA lyase precursor of mammalian species and it also shows good homology with the corresponding protein in 
Table 3. ORF products showing similarities to known protein sequences

\begin{tabular}{|c|c|c|c|c|c|c|}
\hline Product & $\begin{array}{l}\text { Size } \\
\text { (aa) }\end{array}$ & Similar $\operatorname{protein}(s)$ in database & $\begin{array}{l}\text { Homology } \\
\text { score }\end{array}$ & $\begin{array}{l}\text { Percentage } \\
\text { match } \\
\text { (over aa) }\end{array}$ & $\begin{array}{c}\text { Database } \\
\text { accession } \\
\text { no. }\end{array}$ & Motif \\
\hline \multirow[t]{4}{*}{ PpsD } & $533^{*}$ & Peptide synthetase ORF4, B. subtilis & 2766 & $100(533)$ & Z34883 & \\
\hline & & Peptide synthetase ORF3, B. subtilis & 606 & $46(233)$ & Z34883 & \\
\hline & & Peptide synthetase ORF2, B. subtilis & 292 & $48(106)$ & Z34883 & \\
\hline & & Surfactin synthetase, $B$. subtilis & 473 & $42(212)$ & P27206 & \\
\hline \multirow[t]{4}{*}{ PpsE } & 1272 & Fengycin synthetase, $B$. subtilis & 5173 & $80(1222)$ & L42523 & ATP binding \\
\hline & & Peptide synthetase ORF5, B. subtilis & 3722 & $99(717)$ & Z34883 & \\
\hline & & Gramicidin S synthetase II, Bacillus brevis & 1246 & $47(495)$ & D29676 & $\begin{array}{l}\text { Pantetheine } 4^{\prime} \text {-phosphate } \\
\text { site }\end{array}$ \\
\hline & & Surfactin synthetase, B. subtilis & 887 & $57(298)$ & Q04747 & \\
\hline YotA & 510 & f439; unknown function, E. coli & 254 & $51(82)$ & AE000246 & \\
\hline \multirow[t]{3}{*}{ YotC } & 380 & $\begin{array}{l}\text { Acyl-CoA dehydrogenase (butyryl-CoA } \\
\text { dehydrogenase), C. acetobutylicum }\end{array}$ & 523 & $52(186)$ & P52042 & $\begin{array}{l}\text { Acyl-CoA dehydrogenase } \\
\text { I and II signatures }\end{array}$ \\
\hline & & $\begin{array}{l}\text { Hepatic acyl-CoA dehydrogenase short-chain } \\
\text { precursor, } R \text {. norvegicus }\end{array}$ & 478 & $50(199)$ & J05030 & \\
\hline & & YqiN, B. subtilis & 454 & $47(182)$ & D84432 & \\
\hline \multirow[t]{5}{*}{ YotD } & 523 & Acyl-CoA synthetase long chain, B. subtilis & 321 & $43(139)$ & Z75208 & ATP binding \\
\hline & & 4-Coumarate-CoA ligase, Nicotiana tabacum & 316 & $34(187)$ & U50845 & $\begin{array}{l}\text { Prokaryotic membrane } \\
\text { lipoprotein lipid } \\
\text { attachment site }\end{array}$ \\
\hline & & 4-Coumarate-CoA ligase, P. crispum & 307 & $36(175)$ & P14913 & \\
\hline & & 4-Coumarate-CoA ligase, S. tuberosum & 307 & $33(187)$ & P31684 & \\
\hline & & 4-Coumarate-CoA ligase, O. sativa & 238 & $36(122)$ & P17814 & \\
\hline \multirow[t]{4}{*}{ YotE } & 444 & Biotin carboxylase, $M$. jannaschii & 776 & $52(285)$ & U67563 & $\begin{array}{l}\text { Carbamoyl-phosphate } \\
\text { synthase subdomain } \\
\text { signatures }\end{array}$ \\
\hline & & YqhX, B. subtilis & 787 & $52(286)$ & D84432 & \\
\hline & & Biotin carboxylase, Synechococcus PCC 7942 & 991 & $54(347)$ & U59234 & \\
\hline & & Biotin carboxylase, B. subtilis & 773 & $52(286)$ & P49787 & \\
\hline \multirow[t]{2}{*}{ YotF } & 299 & $\begin{array}{l}\text { 3-Hydroxy-3-methylglutaryl-CoA lyase, } \\
\text { Rhodospirillum rubrum }\end{array}$ & 675 & $46(288)$ & U41280 & \\
\hline & & $\begin{array}{l}\text { 3-Hydroxy-3-methylglutaryl-CoA lyase } \\
\text { precursor, H. sapiens }\end{array}$ & 673 & $46(291)$ & P35914 & \\
\hline \multirow[t]{3}{*}{ YotG } & 260 & Enoyl-CoA hydratase, $H$. sapiens & 388 & $46(173)$ & X79888 & $\begin{array}{l}\text { Enoyl-CoA hydratase/ } \\
\text { isomerase signature }\end{array}$ \\
\hline & & $\begin{array}{l}\text { 3-Hydroxybutyryl-CoA dehydratase } \\
\text { (crotonase), C. acetobutylicum }\end{array}$ & 557 & $45(245)$ & P52046 & \\
\hline & & Enoyl-CoA hydratase, $R$. norvegicus & 356 & $46(165)$ & P14604 & \\
\hline \multirow[t]{3}{*}{ YotH } & $280^{*}$ & $\begin{array}{l}\text { Methylmalonyl-CoA decarboxylase, Veillonella } \\
\text { parvula }\end{array}$ & 241 & 39 (114) & A49094 & \\
\hline & & $\begin{array}{l}\text { Propionyl-CoA carboxylase, Mycobacterium } \\
\text { leprae }\end{array}$ & 239 & $43(117)$ & P53002 & \\
\hline & & Propionyl-CoA carboxylase $\mathrm{Yqj} D, B$. subtilis & 234 & $41(117)$ & P54541 & \\
\hline
\end{tabular}

* Truncated proteins.

Gram-positive and Gram-negative bacteria. Finally, the putative product of orf 10 is a polypeptide similar to various prokaryotic and eukaryotic enoyl-CoA hydratases. A summary of the most relevant BLASTX scores is shown in Table 3.

Motif searches revealed that PpsD and PpsE carry potential ATP- and 4'-phosphopantetheine-binding sites, typical of peptide synthetases. Such sites have already been found in the other components of this multienzyme complex (Tognoni et al., 1995). In particular, the consensus sequences SGT(S)TGKPRG, YGP(V/S)TE, NGK, defining the nucleotide-binding sites, were localized at the expected positions of each protein (Cosmina et al., 1993). Based on the known distance in amino acids between two ATP- or phosphopantetheine-binding sites in the same protein (about $1035 \mathrm{aa})$, and the location of the highly conserved 
sequence HHILDGW, it is possible to define the various protein domains. Furthermore, the sequence LGG $(D / H)$ $\mathrm{S}(\mathrm{I} / \mathrm{L})$, which characterizes each amino-acid-binding site according to the description of the activating domains of gramicidin S synthetase (Schlumbohm et al., 1991), is present at the carboxy-terminal region of each domain. PpsC (2555 aa) seems to be organized in two structural domains, like PpsA and PpsB described by Tognoni et al. (1995), while PpsD (3603 aa) and PpsE (1272 aa) have three domains and one domain, respectively.

\section{DISCUSSION}

Three peptide synthetase genes named $p p s$ orf 1 , pps orf 2 and $p p s$ orf 3 (partial) were described in previously published work (Tognoni et al., 1995). The remaining portion of the third sequence and the partial sequence of a fourth gene ( $p p s$ orf 4 ) were available from the Pasteur database (accession number SL675-1). These data, combined with the data obtained in our laboratory, allowed us to construct the functional organization of a single operon. The last gene $(p p s E)$ shares a high degree $(90 \%)$ of identity with the $f e n B$ gene identified by Chen et al. (1995) as forming part of the fengycin synthetase operon. Therefore, it appears that $B$. subtilis strain 168 has a similar set of genes encoding enzymes involved in fengycin synthesis to strain F29-3, in disagreement with the results reported by Chen et al. (1995), in which the corresponding DNA hybridization between strains F293 and 168 could not be detected. Furthermore, downstream of the peptide synthetase genes we have identified five genes encoding enzymes probably involved in fatty acid metabolism, similar to what has been described by the above-mentioned authors. All the products of these genes show similarity with CoA enzymes involved in both biosynthesis and degradation of cellular lipids. Furthermore, YotD shares a region of sequence similarity with gramicidin, tyrocidine and L- $\alpha$-aminoadipylL-cysteinyl-D-valine synthetases (the last one is responsible for the activation step in the biosynthesis of penicillin and cephalosporin). It is known that the multienzymic mechanism of nonribosomal peptide syn- thesis is related to fatty acid synthesis (Zuber et al., 1993), since it uses a pantetheine cofactor and one or more thioesterases (Krätzschmar et al., 1989). Therefore, the proximity of these genes to the peptide synthetase genes may suggest that their products are functionally related to the overall biosynthesis of the lipopeptide.

The Pps proteins form a multienzyme complex composed of ten structural domains, each characterized by several conserved regions and cofactor-binding signatures typical of enzymes that catalyse the biosynthesis of peptide antibiotics. Moreover, it has been reported that a correlation exists between the number and the order of structural domains and the distribution of the amino acids in the lipopeptide surfactin (Cosmina et al., 1993). According to this view and further to our functional analysis conducted by homology searches in databases, we propose the following model for the organization of the fengycin lipopeptide (Fig. 2). Three out of ten amino-acid-binding structural domains have been identified by Tognoni et al. (1995), allowing the assignment of L-Glx to the first and fifth position and D-Orn to the second position. The same authors indicated that domains 3 and 4 may have a leucine-like binding activity, particularly domain 3 , suggesting the presence of this amino acid at the corresponding position of the peptide. Due to this strong homology and the lack of a racemase region, we assume that the L-Ile present in the amino acid composition reported by Vanittanakom \& Loeffler (1986) is present at the corresponding position 3 . The remaining amino acids were putatively assigned on the basis of the following criteria : (i) homology of fengycin structural domains among themselves; and (ii) homology between the structural domains and known amino-acid-binding domains of other peptides, such as gramicidin $S$ and surfactin. Following this approach, we assigned the third L-Glx to position 8 based on the high level of homology (87 and $93 \%$ identity) with the sequences surrounding the conserved PKG and GELC region of the first domain of PpsA and PpsC, respectively. The first domain of $\mathrm{Pps} D$, corresponding to the seventh domain in the entire peptide, shows $54 \%$ identity with the first domain of GrsB (gramicidin

\begin{tabular}{|c|c|c|c|c|c|c|c|c|c|}
\hline & PpsA & & PpsB & & PpsC & & Pps & & PpsE \\
\hline$\square$ & I & & 7 & & & & & $1.7 \%$ & \\
\hline dom 1 & dom2 & dom3 & dom4 & dom5 & dom6 & dom7 & dom8 & dom9 & $\operatorname{dom} 10$ \\
\hline L-Glx & D-Orn & L-Ile & D-allo-Thr & L-Glx & D-Tyr & L-Pro & L-Glx & D-Ala (D-Val) & L-Tyr \\
\hline
\end{tabular}

$=$ thioesterase activity

慻 = racemase activity

Fig. 2. Functional organization of the peptide synthetase complex encoded by the entire pps operon. The domains and the relative amino acids are indicated. 
synthetase II) responsible for the binding of proline, thus allowing the assignment of this amino acid to the corresponding position of the peptide. In the sixth and ninth domains, a 500 aa portion of the carboxy-termini is approximately $50 \%$ homologous to protein portions with racemase activity of SrfA (surfactin synthetase I), GrsA (gramicidin synthetase I) and TycA (tyrocidin synthetase I). This would indicate the presence of $D^{-}$ amino acids at the corresponding positions. The only available position for the remaining L-Tyr could be the tenth, corresponding to the unique domain of PpsE. The similarity between domains 10 and 6 , and the presence of a racemase region at the $3^{\prime}$-end of the latter, would indicate that this position is occupied by $\mathrm{D}-\mathrm{Tyr}$. This is in agreement with the observation made by Cosmina $e t$ al. (1993) that racemic stereoisomers of the same amino acid are characterized by similar motifs, though it is in disagreement with the amino acid sequence of plipastatin (synonymous with fengycin) reported on the basis of structural studies by Nishikiori et al. (1986) in B. cereus strain BMG302-fF67. Domain 9 containing the racemase function, sharing $59 \%$ identity with the third domain, and resembling a leucine-like, apolar amino-acid-binding domain, could be the D-Ala- or $\mathrm{D}$-Val-binding site. Finally, the remaining polar D-allo-Thr would be placed at position 4 , completing the group of four D-amino acids described by Vanittanakom \& Loeffler (1986). Therefore, the amino acid sequence we propose is the following: L-Glx, D-Orn, L-Ile, D-allo-Thr, L-Glx, DTyr, L-Pro, L-Glx, D-Ala (D-Val), L-Tyr. The tenth amino-acid-binding domain is also followed by a thioesterase active site region responsible for the release of the synthesized peptide from the enzyme complex, as already described for the $\mathrm{L}-\alpha$-aminoadipyl-L-cysteinylD-valine and surfactin synthetase systems (van Liempt $e t$ al., 1993). To our knowledge, this is the first attempt to define the amino acid sequence of fengycin on the basis of the DNA sequence of its synthetase operon.

\section{ACKNOWLEDGEMENTS}

We wish to thank M. Coglievina and I. Bertani for their useful technical help in setting up the sequencing methodology and P. Zaccaria for his support in informatic analysis. This work was supported in part by the Commission of the European Communities grant BIO2-CT94-2011 for the sequencing of the Bacillus subtilis genome.

\section{REFERENCES}

Altschul, S. F., Gish, W., Miller, W., Myers, E. W. \& Lipman, D. J. (1990). Basic local alignment search tool. J Mol Biol 215, 403-410.

Borodovsky, M., Rudd, K. E. \& Koonin, V. (1994). Intrinsic and extrinsic approaches for detecting genes in a bacterial genome. Nucleic Acids Res 22, 4756-4767.

Chen, C.-L., Chang, L.-K., Chang, Y.-S., Liu, S.-T. \& Tschen, J. S.-M. (1995). Transposon mutagenesis and cloning of the genes encoding the enzymes of fengycin biosynthesis in Bacillus subtilis. Mol Gen Genet 248, 121-125.

Cosmina, P., Rodriguez, F., de Ferra, F., Grandi, G., Perego, M., Venema, G. \& van Sinderen, D. (1993). Sequence and analysis of the genetic locus responsible for surfactin synthesis in Bacillus subtilis. Mol Microbiol 8, 821-831.

Devereux, J., Haeberli, P. \& Smithies, O. (1984). A comprehensive set of sequence analysis programs for the VAX. Nucleic Acids Res 12, 387-395.

Glaser, P., Kunst, F., Arnaud, M. \& 14 other authors (1993). Bacillus subtilis genome project: cloning and sequencing of the $97 \mathrm{~kb}$ region from $325^{\circ}$ to $333^{\circ}$. Mol Microbiol 10, 371-384.

Hanahan, D. (1985). Techniques for transformation of E. coli. In DNA Cloning : a Practical Approach, vol. 1, pp. 109-132. Edited by D. M. Glover. Oxford: IRL Press.

Itaya, M. \& Tanaka, T. (1991). Complete physical map of the Bacillus subtilis 168 chromosome constructed by a gene-directed mutagenesis method. J Mol Biol 220, 631-648.

Kleinkauf, H. \& von Dobhren, H. (1990). Nonribosomal biosynthesis of peptide antibiotics. Eur J Biochem 192, 1-15.

Klier, A., Msadek, T. \& Rapoport, G. (1992). Positive regulation in the Gram-positive bacterium: Bacillus subtilis. Annu Rev Microbiol 46, 429-459.

Krătzschmar, J., Krause, M. \& Marahiel, M. A. (1989). Gramicidin $\mathrm{S}$ biosynthesis operon containing the structural genes $g r s A$ and $g r s B$ has an open reading frame encoding a protein homologous to fatty acid thioesterases. J Bacteriol 171, 5422-5429.

van Liempt, H., Palissa, H., Pfeifer, E., Schwecke, T., Weekermann, R., von Dobren, H. \& Kleinkauf, H. (1993). ACV synthetase: implications of the amino-acid sequence data for the thiotemplate mechanism of peptide biosynthesis. In 50 Years of Penicillin Application-History and Trends, pp. 136-144. Edited by H. Kleinkauf \& H. von Döhren. Prague: Videopress.

Maget-Dana, R. \& Peypoux, F. (1994). Iturins, a special class of pore-forming lipopeptides: biological and physicochemical properties. Toxicology 87, 151-174.

Marck, C. (1988). DNA Strider : a program for the fast analysis of DNA and protein sequences on the Apple Macintosh family of computers. Nucleic Acids Res 16, 1829-1836.

Murray, M. G. \& Thompson, W. F. (1980). Rapid isolation of high molecular-weight plant DNA. Nucleic Acids Res 8, 4321-4325.

Niaudet, B., Goze, A. \& Ehrlich, S. D. (1982). Insertional mutagenesis in Bacillus subtilis: mechanism and use in gene cloning. Gene 19, 277-284.

Nishikiori, T., Naganawa, H., Muraoka, Y., Aoyagi, T. \& Umezawa, H. (1986). Plipastatins: new inhibitors of phospholipase A2, produced by Bacillus cereus BMG302-fF67. III. Structural elucidation of plipastatins. J Antibiot 39, 755-761.

Pearson, W. R. \& Lipman, D. J. (1988). Improved tools for biological sequence comparison. Proc Natl Acad Sci USA 25, 2444-2448.

Pongor, S., Skerl, V., Cserzo, M., Hatsagi, Z., Simon, G. \& Bevilacqua, V. (1993). The SBASE protein domain library, release 2.0: a collection of annotated protein sequence segments. Nucleic Acids Res 21, 3111-3115.

Pustell, J. \& Kafatos, F. C. (1984). A convenient and adaptable package of computer programs for DNA and protein sequence management, analysis and homology determination. Nucleic Acids Res 2, 643-655.

Sambrook, J., Fritsch, E. F. \& Maniatis, T. (1989). Molecular Cloning: a Laboratory Manual, 2nd edn. Cold Spring Harbor, NY: Cold Spring Harbor Laboratory.

Sanger, F., Nicklen, S. \& Coulson, A. R. (1977). DNA sequencing with chain-terminating inhibitors. Proc Natl Acad Sci USA 74, 5463-5467. 
Schlumbohm, W., Stein, T., Ullrich, C., Vater, J., Krause, M., Marahiel, M., Kruft, V. \& Wittmann-Liebold, B. (1991). An active serine is involved in covalent substrate amino acid binding at each reaction center of gramicidin S synthetase. J Biol Chem 266, 23135-23141.

Short, J. M., Fernandez, J. M., Sorge, J. A. \& Huse, W. D. (1988). Lambda ZAP: a bacteriophage lambda expression vector with in vivo excision properties. Nucleic Acids Res 16, 7583-7600.

Stachelhaus, T., Schneider, A. \& Marahiel, M. A. (1995). Rational design of peptide antibiotics by targeted replacement of bacterial and fungal domains. Science 269, 69-72.

Tognoni, A., Franchi, E., Magistrelli, C., Colombo, E., Cosmina, P. \& Grandi, G. (1995). A putative new peptide synthase operon in Bacillus subtilis: partial characterization. Microbiology 141, 645-648.

Tomino, S., Yamada, M., Itoh, H. \& Kurahashi, K. (1967). Cell-free synthesis of gramicidin S. Biochemistry 6, 2552-2560.

Turgay, K., Krause, M. \& Marahiel, M. A. (1992). Four homologous domains in the primary structure of GrsB are related to domains in a superfamily of adenylate-forming enzymes. Mol Microbiol 6, $529-546$.
Ullrich, C., Kluge, B., Palacz, Z. \& Vater, J. (1991). Cell-free biosynthesis of surfactin, a cyclic lipopeptide produced by Bacillus subtilis. Biochemistry 30, 6503-6508.

Vanittanakom, N. \& Loeffler, W. (1986). Fengycin - a novel antifungal lipopeptide antibiotic produced by Bacillus subtilis F-29-3. J Antibiot 39, 888-901.

Waldrop, G. L., Rayment, I. \& Holden, H. M. (1994). Three dimensional structure of the biotin carboxylase subunit of acetylCoA carboxylase. Biochemistry 33, 10249-10256.

Yanisch-Perron, C., Vieira, J. \& Messing, J. (1985). Improved M13 phage cloning vectors and host strains: nucleotide sequences of the M13mp18 and pUC19 vectors. Gene 33, 103-119.

Zhou, C., Yang, Y. \& Jong, A. Y. (1990). Mini-prep in ten minutes. Biotechniques 8, 172-173.

Zuber, P., Nakano, M. M. \& Marahiel, M. A. (1993). Peptide antibiotics. In Bacillus subtilis and Other Gram-positive Bacteria: Biochemistry, Physiology, and Molecular Genetics, pp. 897-916. Edited by A. L. Sonenshein, J. A. Hoch \& R. Losick. Washington, DC: American Society for Microbiology.

Received 14 April 1997; revised 29 June 1997; accepted 1 August 1997. 